\title{
1. The General Agreement on Tariffs and Trade 1947 (GATT 1947) and the World Trade Organization (WTO) - why join the club?
}

\subsection{INTRODUCTION: THE EARLY DAYS OF THE MULTILATERAL TRADING SYSTEM}

The creation of the multilateral trading system cannot be seen in isolation from the efforts to restore and preserve global peace that started to take shape in the aftermath of the Second World War. ${ }^{1}$ Already during the Second World War, the allied powers, led by the United States, had started thinking about the future of multilateralism. ${ }^{2}$ The Bretton Woods Conference that took place in July 1944 led to agreements on the creation of new international economic institutions. These agreements led to the creation of the World Bank (WB) and the International Monetary Fund (IMF). ${ }^{3}$ The task of the WB can be broadly summarized as 'providing technical assistance to address development-related issues' and the 'financing of development policies' respectively. ${ }^{4}$ The IMF was created with the aim of ensuring the stability of the international monetary system and it 'contributes to macro-economic stability primarily by providing support and advice to countries facing external payment difficulties'. ${ }^{5}$ However, the goals of these institutions were not merely

\footnotetext{
1 Lester, Simon, Mercurio, Bryan and Davies, Arwel (2012), World Trade Law: Text, Materials and Commentary, Oxford, Hart Publishing, at 56.

2 Jackson, John H. (2000), The Jurisprudence of GATT \& the WTO, Cambridge, Cambridge University Press, at 21.

3 Wouters, Jan and De Meester, Bart (2007), The World Trade Organization: A Legal and Institutional Analysis, Antwerp, Intersentia, at 9.

4 Irwin, Douglas A., Mavroidis, Petros C. and Sykes, Alan O. (2008), The Genesis of the GATT, New York, Cambridge University Press, at 99.

5 Wouters, Jan and Odermatt, Jed (2014), "Comparing the "Four Pillars" of Global Economic Governance: A Critical Analysis of the Institutional Design of
} 
economic in nature. ${ }^{6}$ After the establishment of the United Nations (UN) in October 1945, attention shifted towards the creation of institutions that would have to provide for global economic governance. In February 1946, the US proposed a UN Resolution aimed at the convention of a United Nations Conference on Trade and Employment. ${ }^{7}$ It was envisaged that this Conference would serve as a forum for the negotiations on a Charter for an International Trade Organization (ITO) (also referred to as the Havana Charter). ${ }^{8}$ The General Agreement on Tariffs and Trade 'would be an off-shoot of the broader and more ambitious ITO project'. 9

\subsubsection{The International Trade Organization}

The negotiations for an international institution devoted to issues related to international trade were not part of the Bretton Woods framework. As Jackson notes, the evidence available does not support the conclusion that an eventual ITO would be placed at an equal footing with the WB and the IMF. ${ }^{10}$ March 1948 marked the successful conclusion of the negotiations for an ITO Charter. However, due to a lack of agreement within the US Congress, it never entered into force. After the United States in 1951 decided to no longer pursue Congressional approval of the Charter for an ITO, the International Trade Organization was in fact 'stillborn'. None of the other Contracting Parties were interested in establishing an international organization governing trade-related matters, without the United States. ${ }^{11}$ In the absence of an international organization, countries gradually turned to the GATT 1947 to "handle problems concerning their

the FSB, IMF, World Bank, and WTO', Journal of International Economic Law (17) (1), pp. 49-76, at 52.

6 Jackson, John H. (2000), The Jurisprudence of GATT \& the WTO, at 21. Jackson notes that the IMF and WB were also aimed at achieving political goals. In particular he notes that 'the prevention of war and the establishment of a just system of economic relations were as important as the economic benefits that might derive from international trade and economic stability'.

7 UN Economic and Social Council Resolution 1/13, 18 February 1946, UN Doc. E/22.

8 Lester, Mercurio and Davies (2012), World Trade Law, at 56-7.

9 Irwin, Mavroidis and Sykes (2008), The Genesis of the GATT, at 98.

10 Jackson, John H. (1969), World Trade Law and the Law of GATT: A Legal Analysis of the General Agreement on Tariffs and Trade, Charlottesville, VA, The Michie Company/Bobbs Merill.

11 Van den Bossche, Peter and Zdouc, Werner (2013), The Law and Policy of the World Trade Organization, Third Edition, Cambridge, Cambridge University Press, at 78 . 
trade relations'. ${ }^{12}$ In 1955 the GATT Contracting Parties used one of the GATT review sessions that were aimed at examining the operation and functioning of the GATT to draft a new organizational protocol. The protocol was to create an Organization for Trade Co-operation, yet even though this protocol was much more concise than the proposal for an ITO, it also failed to satisfy the US Congress and hence, was also stillborn. ${ }^{13}$

\subsubsection{The General Agreement on Tariffs and Trade 1947}

The substantive negotiations for the General Agreement on Tariffs and Trade 1947 (GATT 1947) were successfully concluded on 30 October 1947. GATT 1947 entered into force on 1 January 1948, by virtue of the Protocol of Provisional Application (PPA). At the time there were 23 Contracting Parties. GATT 1947 was designed as a mechanism to guarantee the value of the tariff concessions made during the negotiations for the ITO. The working assumption had always been that it would be nothing more than an ordinary trade agreement, one that would eventually be placed within the framework offered by the ITO. Consequently, as has been observed by many, 'institutional provisions were not reflected in the GATT text'. ${ }^{14}$ Nevertheless, 'through experimentation and trial and error', the GATT developed a set of rather elaborate procedural rules. ${ }^{15}$ The membership of GATT 1947 was governed by Article XXXII, which stipulates that 'Contracting Parties' are 'those governments which are applying the provisions of this Agreement under Article XXVI or XXXIII or pursuant to the Protocol of Provisional Application'.

\subsubsection{Protocol of Provisional Application}

The PPA was suggested by officials at the US State Department in order to bring the GATT 1947 into effect. ${ }^{16}$ The negotiating authority granted to the US by its legislative branch of government did not extend to many of the rules that were included in the second part of GATT 1947. Hence,

12 Van den Bossche and Zdouc (2013), The Law and Policy of the World Trade Organization, at 78.

13 Jackson, John H. (1997), The World Trading System: Law and Policy of International Economic Relations, Second Edition, Cambridge, MA, MIT Press, at 42 .

14 Irwin, Mavroidis and Sykes (2008), The Genesis of the GATT, at 100.

15 Van den Bossche and Zdouc (2013), The Law and Policy of the World Trade Organization, at 78.

16 Irwin, Mavroidis and Sykes (2008), The Genesis of the GATT, at 100. 
until the US Congress approved the Charter for the ITO, these provisions would only be applied on a provisional basis. Pursuant to the PPA, the Contracting Parties undertook 'to apply provisionally as from 1 January 1948 Parts I and III of the GATT 1947 in full', and Part II 'to the fullest extent not inconsistent with existing legislation'. ${ }^{17}$ The PPA has been described as providing for an 'existing legislation exception', or 'grandfather rights'. Legislation inconsistent with the obligations contained in Part II of the GATT 1947 could be maintained by GATT Contracting Parties. Consequently, there was no real desire on the part of the Contracting Parties to formally adopt GATT 1947 and, hence, the provisions of GATT 1947 were applied through the PPA of 30 October 1947 until $1996 .{ }^{18}$

\subsubsection{The rationale underpinning GATT: reciprocity and non-discrimination}

The Preamble of the General Agreement on Tariffs and Trade 1947 reads (in relevant part):

Recognizing that their relations in the field of trade and economic endeavour should be conducted with a view to raising standards of living, ensuring full employment and a large and steadily growing volume of real income and effective demand, developing the full use of the resources of the world and expanding the production and exchange of goods,

Being desirous of contributing to these objectives by entering into reciprocal and mutually advantageous arrangements directed to the substantial reduction of tariffs and other barriers to trade and to the elimination of discriminatory treatment in international commerce.

The second recital encapsulates the two main principles underpinning the multilateral trading system: reciprocity and non-discrimination. The concept of reciprocity is contained in the idea that negotiating mutual tariff reductions should ultimately lead to an economically more efficient outcome. Already during the early stages of GATT it was envisaged that the Contracting Parties would negotiate binding tariff schedules in which the relevant tariffs for a large set of products would be laid down. This principle was ultimately inscribed in Article II of the GATT 1947, in

17 GATT BISD, Volume IV, 77. See also Van den Bossche and Zdouc (2013), The Law and Policy of the World Trade Organization, at 77.

18 Van den Bossche and Zdouc (2013), The Law and Policy of the World Trade Organization, at 77. 
particular subparagraphs (a) and (b) thereof. The principle of nondiscrimination, on the other hand, was further refined into two distinct forms. First, the concept of Most-Favoured-Nation (MFN) treatment entails that GATT Contracting Parties would no longer provide more favourable treatment - by granting advantages, privileges or immunities to products originating in some states, without providing that same treatment to 'like' products originating in GATT Contracting Parties. This principle is enshrined in Article I:1 of the GATT 1947, which provides:

With respect to customs duties and charges of any kind imposed on or in connection with importation or exportation or imposed on the international transfer of payments for imports or exports, and with respect to the method of levying such duties and charges, and with respect to all rules and formalities in connection with importation and exportation, and with respect to all matters referred to in paragraphs 2 and 4 of Article III, any advantage, favour, privilege or immunity granted by any contracting party to any product originating in or destined for any other country shall be accorded immediately and unconditionally to the like product originating in or destined for the territories of all other contracting parties. [footnote omitted]

The second emanation of the concept of non-discrimination lies in the principle of National Treatment. In essence, this concept required GATT Contracting Parties to treat imported products in the same way as domestic products, both in respect of matters relating to taxation and in respect of internal regulation. The National Treatment obligation was incorporated in Article III of the GATT 1947, which reads (in relevant part):

1. The contracting parties recognize that internal taxes and other internal charges, and laws, regulations and requirements affecting the internal sale, offering for sale, purchase, transportation, distribution or use of products, and internal quantitative regulations requiring the mixture, processing or use of products in specified amounts or proportions, should not be applied to imported or domestic products so as to afford protection to domestic production.

2. The products of the territory of any contracting party imported into the territory of any other contracting party shall not be subject, directly or indirectly, to internal taxes or other internal charges of any kind in excess of those applied, directly or indirectly, to like domestic products. Moreover, no contracting party shall otherwise apply internal taxes or other internal charges to imported or domestic products in a manner contrary to the principles set forth in paragraph 1 .

$[\ldots]$ 
4. The products of the territory of any contracting party imported into the territory of any other contracting party shall be accorded treatment no less favourable than that accorded to like products of national origin in respect of all laws, regulations and requirements affecting their internal sale, offering for sale, purchase, transportation, distribution or use. The provisions of this paragraph shall not prevent the application of differential internal transportation charges which are based exclusively on the economic operation of the means of transport and not on the nationality of the product. [footnotes omitted]

Although the recitals in the preamble, and the subsequent elaboration of the main principles contained therein by means of the obligations in Articles I, II and III of the GATT 1994, provide an indication of the main drivers behind the idea of creating a system aimed at governing the international trade relations of states after the Second World War, the text of the Preamble and these articles does not, as such, explain the economic theory that underpins this type of trade agreement. Why do states voluntarily restrict their sovereignty by binding themselves to a set of international rules that determine the way in which they can conduct their trade policy? ${ }^{19}$ Three approaches that explain the rationale for international trade agreements have been identified. It has been argued that the 'avoidance of terms of trade losses', 'the establishment of economic and political commitments against domestic interests' and 'the pursuit of foreign-policy objectives related to peace and security' may all - to varying degrees - explain the existence of trade agreements such as GATT. ${ }^{20}$ These three approaches will be discussed in this subsection. It should be noted, however, that the rationale behind the creation of the multilateral trading system as such is, in most cases, different from the motivation of individual states and customs territories to join the system at a later stage. The rationale of their accession bids will be examined in more detail in section 1.3 .

\subsection{Avoiding terms-of-trade losses The first of the three} approaches that may explain the intention of the US and other original Contracting Parties in negotiating the GATT relates to the idea that a multilateral approach towards tariff liberalization is economically more efficient than a unilateral one. In a situation in which states seek the

19 Ossa, Ralph (2011), "A "New Trade" Theory of GATT/WTO Negotiations', Journal of Political Economy (119) (1), pp. 122-52.

20 Van den Bossche and Zdouc (2013), The Law and Policy of the World Trade Organization, at 197. 
unilateral liberalization of tariffs, they will face a 'prisoner's dilemma' which, as has been shown by many economists, leads to an inefficient outcome:

Acting independently, countries may not be able to avoid the inefficient equilibrium because, if one of them were to reduce its tariffs alone, the other country would still have a unilateral incentive to maintain its duties on the tariff-reducing country. ${ }^{21}$

It has been argued that the principles of reciprocity and nondiscrimination, as contained in Articles I, II and III of the GATT 1994, operate as 'rules that work in concert to guide governments toward efficient multilateral trade agreements'. ${ }^{22}$ However, others have argued that, in practice, the principles of reciprocity and the principle of Most-Favoured-Nation treatment are, in fact, opposing and that the pursuit of Most-Favoured-Nation treatment, basing free trade negotiations on the idea of reciprocity, and the pursuit of a near-universal membership of GATT are fundamentally at odds with each other. ${ }^{23}$ According to this view it would be economically more efficient if more emphasis could be placed on reciprocity, even if this would mean that the pursuit of a universal multilateral trading system would need to be abandoned. As will be explained subsequently, however, the GATT, and eventually the WTO continued in their pursuit of universal membership. The question is whether the concern expressed - that in its current form the GATT would end up as a 'seriously degenerated, nominally universal, but in practice highly unstable system, increasingly open to the use of naked power' has become a reality. ${ }^{24}$ In the end, it is generally considered that it is unlikely that terms-of-trade type motivations were the main - let alone the only - driver behind the creation of the GATT.

1.1.2.2.2 Establishing commitments In addition to the terms-of-trade approach, two types of commitment theories have been used to explain the creation of the GATT in the period immediately after the Second World War. Both theories operate from the idea that governments pursue

\footnotetext{
21 Irwin, Mavroidis and Sykes (2008), The Genesis of the GATT, at 178.

22 Bagwell, Kyle and Staiger, Robert W. (1999), 'An Economic Theory of GATT', The American Economic Review (89) (1), pp. 215-48, at 241.

23 Curzon, Gerard and Curzon, Victoria (1989), 'Non-Discrimination and the Rise of "Material" Reciprocity', The World Economy (12) (4), pp. 481-500, at 497.

24 Curzon and Curzon (1989), Non-Discrimination and the Rise of 'Material' Reciprocity, at 498.
} 
trade policies that are aimed at the maximization of national welfare. From this perspective, binding the country in question to a set of international norms - in the form of trade agreements - is useful to strengthen the government's bargaining position against domestic interest groups. One can distinguish between economic commitment and political commitments. ${ }^{25}$ At the same time, it should be recognized that neither of these two commitment theories probably fully explains states' desire to create a multilateral trading system along the lines of GATT. ${ }^{26}$

\subsection{Foreign-policy objectives 'When goods don't cross borders,} soldiers will.' This quote, often, yet perhaps mistakenly, attributed to French liberal economist Frédéric Bastiat, perhaps best sums up the third approach used to explain the creation of the multilateral trading system. ${ }^{27}$ After the Second World War, governments may not only have been interested in improving the economic situation of their country, or even merely their trade balance. Nor may they have intended to create GATT in order to bind subsequent government. Rather, it is likely that more general foreign-policy objectives - such as the creation of a more stable economic climate - may have been important drivers behind the creation of the multilateral trading system. It has been stated that 'the broad objective [of the GATT] is to help to maintain international political stability by establishing rules of "good behaviour" as well as mechanisms for settling disputes'.28 Many scholars in the field of political science have tried to explain the creation of the GATT in light of the desire of states to prevent future situations of (armed) conflict. Indeed, some accounts provide evidence for the argument that some of the driving powers during the GATT negotiations had peace, stability and security in mind when trying to develop a set of rules for the conduct of international trade. During a meeting in April 1947, US Negotiator Clair

25 Irwin, Mavroidis and Sykes (2008), The Genesis of the GATT, at 184.

26 Irwin, Mavroidis and Sykes (2008), The Genesis of the GATT, at 188.

27 Snow, Nicolas (2010), If Goods Don't Cross Borders ..., Foundation for Economic Education, 26 October. Available at http://fee.org/resources/detail/ifgoods-dont-cross-borders (last accessed at 1 June 2017). Snow explains that it is unclear whether this sentence can be attributed to Bastiat. He refers to a quote by 19 th century liberal Otto T. Mallery, who coined the quote 'If soldiers are not to cross international boundaries, goods must do so. Unless the Shackles can be dropped from trade, bombs will be dropped from the sky.'

28 Robert E. Baldwin (1986), as cited by Irwin, Mavroidis and Sykes (2008), The Genesis of the GATT, at 188. In Baldwin's view the main rationale for establishing the GATT was a political one. 
Wilcox made reference to a speech given by President of the United States Harry S. Truman, in which he stated:

If the nations can agree to observe a code of good conduct in international trade, they will cooperate more readily in other international affairs. Such agreement will prevent the bitterness that is engendered by an economic war. It will provide an atmosphere congenial to the preservation of peace. ${ }^{29}$

The idea that international trade could contribute in a positive manner to establishing peace, security and stability had, however, been formulated almost a century earlier by John Stuart Mill. In his 1848 work Principles of Political Economy, he stated the following:

[c]ommerce first taught nations to see with good will the wealth and prosperity of one another. Before, the patriot, unless sufficiently advanced in culture to feel the world his country, wished all countries weak, poor, and ill-governed, but his own: he now sees in their wealth and progress a direct source of wealth and progress to his own country. It is commerce which is rapidly rendering war obsolete, by strengthening and multiplying the personal interests which are in natural opposition to it. And it may be said without exaggeration that the great extent and rapid increase of international trade, in being the principal guarantee of the peace of the world, is the great permanent security for the uninterrupted progress of the ideas, the institutions, and the character of the human race. ${ }^{30}$

International trade as a condition for international peace and security may indeed have been one of the motivations for the negotiators of the GATT. $^{31}$ An international set of rules that governs international trade could arguably strengthen the capacity of international trade to bring about peace. Nevertheless, even though this third approach may also - to a certain extent - explain the creation of the GATT, similarly to the first and second approach, it does not in and of itself constitute the main reason for establishing the multilateral trading system. Rather, these approaches and theories should be 'understood as complementary, rather

29 President of the United States of America, Harry S. Truman (1947), Address on Foreign Economic Policy, delivered at Baylor University, 6 March. Available at http://www.presidency.ucsb.edu/ws/?pid=12842 (last accessed at 1 June 2017).

30 Mill, John Stuart (1909), Principles of Political Economy with some of their Applications to Social Philosophy, First Published 1848, 7th Edition, 1909, London; Longmans, Green and Co., at III.17.14.

31 Gowa, Joanne and Hicks, Raymond (2013), 'Politics, Institutions, and Trade: Lessons of the Interwar Era', International Organization (67) (3), pp. 439-67. 
than competing explanations for the remarkable achievements that led to the GATT in $1947^{\prime} .32$

\subsection{THE WORLD TRADE ORGANIZATION}

The WTO was born out of the eighth round of multilateral trade negotiations conducted in the framework of the GATT 1947. By the early 1980s, the main Contracting Parties to the GATT 1947 realized that an enhanced institutional framework was required to address the complexities posed by the globalization of the economy. GATT 1947 had provided a useful framework for the negotiation of tariff reductions, but as trade in services and international investment - two areas not regulated by GATT 1947 - began to increase, the lack of rules governing these areas became more apparent. Additionally, although the GATT 1947 did have a rules-based dispute settlement system, the attitude of some Contracting Parties towards this system became a source of concern. Non-compliance with Reports of GATT Panels was increasing, and the need for a more robust set of rules on dispute settlement was felt by many of the Contracting Parties. The Uruguay Round of Multilateral Trade Negotiations was intended to address many of the areas that had been left unregulated by GATT 1947, or which had not been regulated in sufficient detail in light of the changing nature of global commerce. After seven and a half years of intense negotiations, 123 participating governments concluded the WTO Agreement. ${ }^{33}$ The WTO superseded GATT as an international organization, but the original rules contained in the GATT 1947 were transposed into the new legal framework. The General Agreement on Tariffs and Trade 1994 (GATT 1994) incorporates the provisions of the GATT 1947 by reference. Article 1(a) of the GATT 1994 provides that:

1. The General Agreement on Tariffs and Trade 1994 ('GATT 1994') shall consist of:

(a) the provisions in the General Agreement on Tariffs and Trade, dated 30 October 1947, annexed to the Final Act Adopted at the Conclusion of the Second Session of the Preparatory Committee of the United Nations Conference on Trade and Employment (excluding the Protocol of Provisional Application), as rectified, amended or modified by the terms of legal

\footnotetext{
32 Irwin, Mavroidis and Sykes (2008), The Genesis of the GATT, at 200.

33 WTO, Understanding the WTO. Available at https://www.wto.org/english/ thewto_e/whatis_e/tif_e/fact5_e.htm (last accessed at 1 June 2017).
} 
instruments which have entered into force before the date of entry into force of the WTO Agreement;

In addition to new rules on issues relating to anti-dumping, subsidies, technical barriers to trade, customs valuation and many others, several institutional changes were part of the results of the Uruguay Round. The dispute settlement procedures were altered fundamentally and a Dispute Settlement Body was created. Moreover, the dispute settlement rules now included a well-known 'reversed-consensus' rule, which entails that in respect of a number of provisions, a particular decision is taken, unless there is a consensus not to take that particular decision. ${ }^{34}$ In the field of accession, however, there were no major changes. The main provision of the GATT 1947 on this issue, Article XXXIII, was more or less copied into the text of the WTO Agreement. Article XII of the WTO Agreement provides (in relevant part):

1. Any State or separate customs territory possessing full autonomy in the conduct of its external commercial relations and of the other matters provided for in this Agreement and the Multilateral Trade Agreements may accede to this Agreement, on terms to be agreed between it and the WTO. Such accession shall apply to this Agreement and the Multilateral Trade Agreements annexed thereto.

2. Decisions on accession shall be taken by the Ministerial Conference. The Ministerial Conference shall approve the agreement on the terms of accession by a two-thirds majority of the Members of the WTO.

The essence of the central phrase of Article XXXIII GATT 1947, 'on terms to be agreed between such government and the CONTRACTING PARTIES', remains unaltered with Article XII WTO Agreement stating 'on terms to be agreed between it [any State or separate customs territory wishing to join the WTO] and the WTO'. Subsequent chapters will discuss the different types of WTO membership (original and nonoriginal) and the accession procedure in more detail (see in particular sections 2.3.2.2 and 4.2.2.3).

34 The reversed consensus principle can, inter alia, be found in Article 6.1 DSU (on the establishment of panels), Article 16.4 DSU (on the adoption of panel reports) and Article 17.14 DSU (on the adoption of Appellate Body reports). 


\subsection{RATIONALES FOR ACCESSION}

The rationale for the creation of the multilateral trading system has been described briefly in section 1.1.2.2. The rationale for the creation for the system as such, however, has to be distinguished from the rationales that have driven and drive the accession bids of states and customs territories looking to become part of that very system. States and customs territories historically have had a wide variety of reasons to seek accession to the multilateral trading system. Economic motives have in most cases been the primary driver behind the desire of states to join the GATT/WTO system. Since the creation of the GATT 1947, the principle of non-discrimination has provided states with an enhanced sense of security that in conducting their trade relations with other Contracting Parties their exporters would not be subject to discriminatory treatment. Moreover, the practice of binding tariff concessions multilaterally has provided producers and exporters with a more stable international playing field. Although the question of whether the GATT/WTO system has in practice led to an increase in global trade, or even an increase in global economic welfare, is subject to debate, it cannot be denied that the system has provided economic actors with more security, stability and predictability. These economic motives will be discussed in the first subsection. GATT/WTO membership has also been pursued for, what might be called, political motives. Becoming a Contracting Party to GATT or a Member to the WTO has historically signalled to the international community that the acceding state has obtained a level of "political maturity' at the international level. Additionally, it provides a sign to potential investors that the state in question is willing and able to adhere to a set of binding international rules that will inform the way in which the state will conduct its internal trade policy. GATT/WTO membership thus makes it more attractive for a foreign investor to open up a branch in a state or customs territory. Aside from economic and political motives that underpin a state's desire to join the multilateral trading system, GATT/WTO accession also bring externalities that - although not the main driver behind an accession bid - may positively influence the economic development of the acceding state. These factors will be discussed in the third subsection. Lastly, considering the proliferation of preferential trade agreements (PTAs), regional trade agreements (RTAs) and plurilateral trade agreements, the question arises how this development impacts the desire of states who are not yet WTO Members to join the organization. ${ }^{35}$ Does the WTO

35 Some recent initiatives include the Transatlantic Trade and Investment Partnership (TTIP) between the European Union and the United States, the 
perhaps provide for a 'safe-haven' in times of multi-polar - rather than multilateral - global economic governance?

\subsubsection{Economic Motives for WTO Accession}

Obtaining WTO membership comes at a cost. As will be explained further on in this contribution, the WTO accession process is often long and arduous. States are required to give up most of their existing instruments aimed at protecting domestic industries. Opening up domestic markets may come at a cost to inefficient industries which may not be able to survive foreign competition. Disruptive effects may lead to (temporary) peaks in unemployment. Why then have states continued to seek accession to the multilateral trading system, be it to the GATT 1947 or to the WTO? A first argument relates to the aforementioned 'terms of trade' theory. If states are willing to undergo, as will be established in subsequent chapters, a lengthy and sometimes costly accession process, it is to be expected that the economic gains offered by WTO membership outweigh these costs - at least to a certain extent. ${ }^{36}$ Consequently, it might be so that membership to the GATT/WTO increases the level of trade in a former non-Member. A second explanation is derived from the fact that, at least in theory, exporters in a WTO Member benefit from non-discriminatory treatment from other WTO Members. The MostFavoured-Nation (MFN) treatment obligation and its underlying principle may therefore still provide a ground to seek accession to the WTO. ${ }^{37}$ Thirdly, states may have country-specific economic interests that underpin their desire to join the multilateral trading system.

\subsubsection{Does the GATT/WTO increase trade and foreign direct investment?}

Economic scholarship focusing on the effects of the creation of, and accession to, the multilateral trading system has mostly studied the

Trans-Pacific Partnership (TPP), the Regional Comprehensive Economic Partnership (RCEP) and the Trade in Services Agreement (TISA).

36 Allee, Todd L. and Scalera, Jamie E. (2012), 'The Divergent Effects of Joining International Organizations: Trade Gains and the Rigors of WTO Accession', International Organization (66) (2), pp. 243-76; Hong, Chang (2013), 'The Political Economy of Tariff Protection in China: Evidence from the WTO Accession', Canadian Journal of Economics (46) (4), pp. 1295-316.

37 Egger, Peter H. and Olarreaga, Marcelo (2014), 'Special Issue: The Political Economy of Multilateral Trade Negotiations', The Review of International Organizations (9) (2), pp. 135-42. 
question whether being a Member to this system influences the amount of trade relative to gross domestic product (GDP) of a particular country. This section summarizes the key findings of economic research in this area. ${ }^{38}$ One central question that has been addressed is whether the system introduced by GATT, and subsequently evolved into the WTO, increases trade. ${ }^{39}$ One strand of scholarship has argued that the effect of the GATT/WTO on trade is limited. ${ }^{40}$ Similarly, the argument has been made that - contrary to what one might have expected - membership of the multilateral trading system is not automatically associated with more liberal trade policy. ${ }^{41}$ Others have argued that there is a visible effect of the GATT/WTO system on the growth of international trade. ${ }^{42}$ Accordingly it has been found that " $[\mathrm{t}]$ rade among those with standing in the GATT/WTO was considerably higher than what one would predict, based purely on proximity, national income, and other non-political variables' ${ }^{43}$ Subsequent studies have further refined the applicable methodology by not taking into account sectors that are not within the purview

38 Kohl, Tristan and Trojanowska, Sofia (2015), 'Heterogeneous Trade Agreements, WTO Membership and International Trade: An Analysis Using Matching Econometrics', Applied Economics (47) (33), pp. 3499-509.

39 An expected increase in trade seems to be one of the main drivers behind accession bids. See, for example, Babetskaia-Kukharchuk, Oxana and Maurel, Mathilde (2004), 'Russia's Accession to the WTO: The Potential for Trade Increase', Journal of Comparative Economics (30), pp. 680-99.

40 Rose, Andrew K. (2004), 'Do We Really Know That the WTO Increases Trade?', The American Economic Review (94) (1), pp. 98-113; and Rose, Andrew K. (2007), 'Do We Really Know That the WTO Increases Trade? Reply', The American Economic Review (97) (5), pp. 2019-25.

41 Rose, Andrew K. (2004), 'Do WTO Members Have More Liberal Trade Policy?', Journal of International Economics (63) (2), pp. 209-35; see also Chandra, Piyush (2014), 'WTO Subsidy Rules and Tariff Liberalization: Evidence from Accession of China', The Journal of International Trade \& Economic Development: An International and Comparative Review (23) (8), pp. 1170-205. 42 Tomz, Michael, Goldstein, Judith and Rivers, Douglas (2007), 'Membership Has Its Privileges: The Impact of GATT on International Trade', The American Economic Review (97) (5), pp. 2005-18; Chang, Pao-Li and Lee, Myoung-Jae (2011), 'The WTO Trade Effect', Journal of International Economics (85), pp. 53-71, at 69, noting that 'membership in the GATT/WTO has a significant trade-promoting effect for dyads that have both chosen to be members'.

43 Goldstein, Judith L., Rivers, Douglas and Tomz, Michael (2007), 'Institutions in International Relations: Understanding the Effects of the GATT and the WTO on World Trade', International Organization (61) (1), pp. 37-67, at 63. 
of the WTO. ${ }^{44}$ Since the WTO disciplines on agricultural and textiles trade are relatively weak, it has been argued that these sectors should be excluded from the analysis. Moreover, trade in oil should also be excluded given that the WTO does not address this particular type of commodity. Through this refined analysis, it has been found that the GATT/WTO system increases trade for its Members by approximately 30 per cent on average. ${ }^{45}$ Indeed, it has been argued that 'the GATT/WTO has done a splendid job of promoting trade'. ${ }^{46}$ However, this conclusion comes with the caveat that four identified asymmetries in the system cause an uneven distribution of the growth in trade. Most importantly, it has been found that, on average, developing countries' imports have not increased as a result of WTO membership. ${ }^{47}$ This suggests that the effect on trade is perhaps most visible in the field of exports. In trying to reconcile these apparently conflicting findings, it has been concluded that, indeed, '[j] oining the WTO is all about exports'. ${ }^{48}$ The question that will always be present in this context is one of attribution. To what extent can the set of rules developed in the context of the GATT/WTO, and their subsequent enforcement through its dispute settlement mechanism, be seen as the cause for the growth in trade - let alone global economic welfare? ${ }^{49}$ In any event, the potential economic benefits of GATT/WTO membership should not be defined narrowly in terms of the size of international trade. Indeed, as has been acknowledged in the scholarship that has been referenced here, other factors such as the reducing cost of transportation and regional association have undoubtedly also contributed to the increase of international trade. One study argues that the role of GATT/WTO should not be considered merely from a numerical perspective. Rather, the multilateral trading system should be considered as a

44 Kim, Myeong Hwan (2010), 'Does the WTO Promote Trade? Further Evidence', The Journal of International Trade \& Economic Development: An International and Comparative Review (19) (3), pp. 421-37.

45 Kim (2010), Does the WTO Promote Trade? Further Evidence, at 430.

46 Subramanian, Arvind and Wei, Shang-Jin (2007), 'The WTO Promotes Trade, Strongly but Unevenly', Journal of International Economics (72), pp. 151-75, at 173; see also Chang and Lee (2011), The WTO Trade Effect, at 69.

47 Subramanian and Wei (2007), The WTO Promotes Trade, Strongly but Unevenly, at 173 .

48 Balding, Christopher (2010), 'Joining the World Trade Organization: What Is the Impact?', Review of International Economics (18) (1), pp. 193-206.

49 Anderson, Kym (2014), 'Contributions of the GATT/WTO to Global Economic Welfare: Empirical Evidence', Journal of Economic Surveys (30) (1), pp. 56-92. 
forum that fosters coordination between countries. It has been suggested that ' $[\mathrm{b}] \mathrm{y}$ being part of the negotiating structure, countries form relationships and put their policies and priorities transparently on the table. In a word, they build trust, which is fundamental to facilitating international trade.'50 Looking more broadly at the question of how GATT/WTO accession influences growth and investment, it has been found that if a country is required to undertake substantial domestic reforms in order to be accepted by the WTO, this is associated with 'significant increases in growth and investment'. ${ }^{51}$ More specific findings on the relationship between WTO accession and foreign direct investment have been made with regard to Viet Nam. In a case study, it was found that the country's WTO accession in 2006 has had a 'strong and positive impact on Vietnam's imports and inward FDI [foreign direct investment]'.52 It has been observed that, more generally, FDI increases with GATT/WTO membership. ${ }^{53}$ The positive impact of WTO accession on a country's investment climate has also been revealed in the context of the accession of Least-Developed Countries (LDCs). WTO accession will require these countries to implement domestic reforms, also related to rule of law issues, which will make them more attractive as a potential host-state for FDI. ${ }^{54}$ Nevertheless, although WTO accession may have a positive influence on FDI because of the fact that WTO accession requires certain domestic reforms, the causality remains precisely between these domestic reforms and an increase in FDI. Consequently, where a country decides

50 Grant, Jason H. and Boys, Kathryn A. (2012), 'Agricultural Trade and the GATT/WTO: Does Membership Make a Difference?', American Journal of Agricultural Economics (94) (1), pp. 1-24, at 20.

51 Tang, Man-Keung and Wei, Shang-Jin (2006), Is Bitter Medicine Good for You? The Economic Consequences of WTO/GATT Accessions, paper presented at the Trade Conference, Research Department hosted by the International Monetary Fund, 13 April 2006, at 22; Tang, Man-Keung and Wei, Shang-Jin (2009), 'The Value of Making Commitments Externally: Evidence from WTO Accessions', Journal of International Economics (78) (2), pp. 216-29.

52 Pham, Thi Hong Hanh (2011), 'Does WTO Accession Matter for the Dynamics of Foreign Investment and Trade? Vietnam's New Evidence', Economics of Transition (19) (2), pp. 255-85, at 282.

53 Dreher, Axel, Mikosh, Heiner and Voigt, Stefan (2015), 'Membership Has Its Privileges: The Effect of Membership in International Organizations on FDI', World Development (66), pp. 346-58, at 354.

54 Chekol, Abebe Abebayehu (2008), Accession to the WTO: Brightening the Prospect for Attraction of Investment? A Least-Developed Country's Perspective, CEPMLP Annual Review, Volume 12 (2007-08). Available at http://www. dundee.ac.uk/cepmlp/gateway/index.php?news $=29870$ (last accessed at 1 June 2017). 
to implement the necessary policy changes at an earlier stage, FDI in the affected sectors may already increase prior to WTO accession. ${ }^{55}$ Economic scholarship does not seem to support the conclusion that WTO membership in itself is enough to trigger domestic reform. Nevertheless, WTO accession aspirations will, inevitably, often coincide with a drive towards more market-oriented policies and an improved system of governance.

\subsubsection{The benefits of non-discrimination}

The principle of non-discrimination has always been one of the cornerstones of the multilateral trading system. As explained, the MFNtreatment obligation and the National Treatment obligation required GATT Contracting Parties not to discriminate between and against imported products. Those states and customs territories that were not a Contracting Party to the GATT or are not a Member of the WTO did not, and do not, benefit from the treatment prescribed by these two obligations. There is no obligation on WTO Members to extend MFN-treatment or National Treatment to the products from non-WTO Members. Consequently, the protection afforded by the MFN-treatment obligation and the National Treatment obligation is an incentive for states and customs territories to seek accession to the multilateral trading system. Historically, this has been the driver behind many of the GATT-accession bids from smaller economies. As has been noted, these countries began to 'appreciate multilateralism in trade as a shield of protection against bilateral pressures from trading powers, assuring non-discriminatory treatment and fair procedures'.56 Similarly, planned-economy countries, such as Yugoslavia, Poland, Romania and Hungary saw the benefit of the protection offered by these principles and consequently acceded to the GATT in the late 1960s and early 1970s.

\subsubsection{Country-specific and sector-specific impacts of accession}

In a number of accessions, certain country-specific or sector-specific interests influenced the desire of the state in question to join the multilateral trading system. In a study on agricultural trade and the GATT/WTO, mentioned in the previous subsection, it was found that

55 Desta, Melaku Geboye (2009), 'Accession for What? An Examination of Ethiopia's Decision to Join the WTO', Journal of World Trade (43) (2), pp. 339-62, at 357.

56 Benedek, Wolfgang and Ginther, Konrad (1988), Planned-Economy Countries and GATT: Legal Issues of Accession, in German Yearbook of International Law/Jahrbuch für Internationales Recht (31), pp. 70-106, at 72. 
accession 'generates sizable trade flow gains and establishes an atmosphere conducive to commercial exchange'.57 These findings are consistent with studies carried out with respect to agricultural trade and food security in China. It has been observed that WTO accession has been beneficial to China's agricultural sector, yet it has also been noted that, again, additional steps are necessary to 'improve transparency, information, quality, sanitary measures and other measures in order to benefit fully from opportunities'. ${ }^{58}$ Turning to more country-specific findings, one study revealed that accession may also have a positive impact on the reduction of household poverty. ${ }^{59}$ Some studies have also addressed the impact of WTO accession at the firm-level or within specific sectors. ${ }^{60}$

\subsubsection{Political Motives for WTO Accession}

In addition to the economic rationale for WTO accession, political considerations may also play an important role in the desire of states to become part of the multilateral trading system. ${ }^{61}$ It has been shown that 'geopolitical factors attract some countries to the regime while making others hesitant to join'. These findings have been explained by referencing the example of the accession of formerly communist states in the second half of the 20th century. The GATT 'enticed new members with

57 Grant and Boys (2012), Agricultural Trade and the GATT/WTO: Does Membership Make a Difference?, at 20; Li, David L. and Wu, Changqi (2004), GATT/WTO Accession and Productivity, in Ito, Takatoshi and Rose, Andrew K. (eds) (2004), Growth and Productivity in East Asia, NBER-East Asia Seminar on Economics, vol. 13, Chicago, University of Chicago Press.

58 Palma, Carolina (2015), 'WTO Implications of China's Food Security

Policy', Global Trade and Customs Journal (10) (6), pp. 217-27, at 224.

59 Rutherford, Thomas F. and Tarr, David G. (2008), 'Poverty Effects of Russia's WTO Accession: Modeling "Real" Households with Endogenous Productivity Effects', Journal of International Economics (75), pp. 131-50, at 149; Tarr, David G. (2007), 'Russian Accession to the WTO: An Assessment', Euroasian Geography and Economics (48) (3), pp. 306-19.

60 Jiang, Neng and Kattuman, Paul A. (2012), 'China's WTO Accession and Long-Term Profitability of Chinese Firms', International Journal of the Economics of Business (19) (1), pp. 53-73; Mattoo, Aaditya (2003), 'China's Accession to the WTO: The Services Dimension', Journal of International Economic Law (6) (2), pp. 299-339; Li, Shanshan and Xu, Ningxiang (2015), 'The Influences of WTO Accession on China's State-Owned Enterprises', Open Journal of Business and Management (3), pp. 192-8.

61 McKenzie, Francine (2008), 'GATT and the Cold War: Accession Debates, Institutional Development and the Western Alliance, 1947-1959', Journal of Cold War Studies (10) (3), pp. 78-109. 
lenient conditions when engaged in rivalry with the Soviet bloc, and only began to impose strict conditions when the end of Cold War reduced the salience of foreign policy in the domain of economic decision-making' ${ }^{62}$ Another example is formed by the applications for accession to the WTO from Iraq and Afghanistan in the aftermath of US-led military interventions in these countries. Whereas these political motives stem, to a large extent, from geopolitical considerations, domestic politics may also serve as the basis for a WTO accession bid. Such political considerations have also been mentioned as the driver behind China's accession bid to the WTO in 2001.63 It has been argued that China's desire to join the WTO did not only stem from 'a desire to protect itself from potential economic blackmail by the United States', but also reflects the realization that China's economic institutions have to be aligned 'with the economic institutions of modern capitalist economies'.64 Moreover, it has been suggested that China's leadership 'is confident that its explicit embrace of capitalist institutions under WTO auspices would be seen by the general Chinese public (and the Chinese elite) as a step forward in the reform process rather than as surrender of China's sovereignty in economic experimentation'.65

\subsubsection{Externalities of WTO Accession}

In addition to the expected or desired effects of WTO accession that have been discussed in previous sections, states may experience societal changes that had not been expected, or were not the main reason for the accession. These externalities, or unexpected and unintended consequences, of WTO accession are the subject of this subsection. One of the main externalities brought about by WTO accession and highlighted in

62 Davis, Christina L. and Wilf, Meredith (2013), 'Joining the Club: Accession to the GATT/WTO', The Journal of Politics (79) (3), pp. 964-78; see also Davis, Christina and Wilf, Meredith (2015), WTO Membership, in Martin, Lisa L. (ed.), The Oxford Handbook of the Political Economy of International Trade, New York, Oxford University Press, at 392.

63 In this respect note the political sensitivities surrounding the WTO accession of Chinese Taipei (or Taiwan). See Charnovitz, Steve (2006), 'Taiwan's WTO Membership and Its International Implications', Asian Journal of WTO and International Health Law and Policy (1), pp. 401-31.

64 Sachs, Jeffrey D. and Woo, Wing Thye (2003), 'China's Economic Growth after WTO Membership', Journal of Chinese Economic and Business Studies (1) (1), pp. 1-31, at 25.

65 Sachs and Woo (2003), China's Economic Growth after WTO Membership, at 26 . 
academic literature is the impact it has on, what will be called, the system of governance and the rule of law in the acceding state. ${ }^{66}$ Similarly, it may also impact the legal culture in the acceding state. ${ }^{67}$ As will be explained in subsequent chapters, accession to the WTO does not only require states to liberalize their markets, lower their tariffs and grant

66 Elgindi, Ali Ibn Abi Talib A. and Lunenborg, Peter (2012), 'The WTO Accession Process and Non-Economic Considerations', Global Trade and Customs Journal (7) (11-12), pp. 461-5; Shaffer, Gregory (2015), 'How The World Trade Organization Shapes Regulatory Governance', Regulation and Governance (9) (1), pp. 1-15, at 8; Guohua, Yang and Jin, Cheng (2001), 'The Process of China's Accession to the WTO', Journal of International Economic Law (4) (2), pp. 297-328.

67 See, in respect of China, Gao, Henry (2007), 'Taming The Dragon: China's Experience in the WTO Dispute Settlement System', Legal Issues of Economic Integration (34) (4), pp. 369-92; Qin, Julia Ya (2007), 'Trade, Investment and Beyond: The Impact of WTO Accession on China's Legal System', The China Quarterly (191), pp. 720-41; Don Harpaz, Marcia (2010), 'Sense and Sensibilities of China and WTO Dispute Settlement', Journal of World Trade (44) (6), pp. 1155-86, at 1178; Don Harpaz, Marcia (2011), 'China's WTO Compliance-Plus Anti-Dumping Policy', Journal of World Trade (45) (4), pp. 726-66; Toohey, Lisa (2011), 'China and the World Trade Organization: The First Decade', International and Comparative Law Quarterly (60) (3), pp. 78898; Zhuang, Wei (2011), 'An Empirical Study of China's Participation in the WTO Dispute Settlement Mechanism: 2001-2010', The Law and Development Review (4) (1), pp. 217-46; Kennedy, Matthew (2012), 'China's Role in WTO Dispute Settlement', World Trade Review (11) (4), pp. 555-89; Chi, Manjiao (2012), 'China's Participation in WTO Dispute Settlement over the Past Decade: Experiences and Impacts', Journal of International Economic Law (15) (1), pp. 29-49; Mercurio, Bryan and Tyagi, Mitali (2012), China's Evolving Role in WTO Dispute Settlement: Acceptance, Consolidation and Activation, in Herrmann, Christoph and Terhechte, Jörg Philipp (eds) (2012), European Yearbook of International Economic Law, vol. 3, Heidelberg, Springer; Guohua, Yang (2015), 'China in the WTO Dispute Settlement: A Memoir', Journal of World Trade (49) (1), pp. 1-18; Li, Liao and Minyou, Yu (2015), 'Impact of the WTO on China's Rule of Law in Trade: Twentieth Anniversary of the WTO', Journal of World Trade (49) (5), pp. 837-72, at 872. Li and Minyou note that '[i]t is another long march that establishment of the rule of law in China, which could not be realized without cultivating the rule of law in trade within China. As the first major power of trade in goods and the second largest economy, China still has considerable progress to make for the rule of law in trade.' Burnay, Matthieu and Wouters, Jan (2015), The EU and China in the WTO: What Contribution to the International Rule of Law? Reflections in Light of the Raw Materials and Rare Earths Disputes, in Wang, Jianwei and Song, Weiqing (eds), China, the European Union, and International Politics of Global Governance, London, Palgrave MacMillan (forthcoming). 
non-discriminatory treatment to imported products. Rather, the obligations that are contained in the WTO agreements require WTO Members to establish - albeit to a limited extent - a system of governance that provides for access to an independent court of law. ${ }^{68}$ Additionally, the transparency obligations contained in some of the WTO agreements force WTO Members to establish policies that allow for the publication of official documents. ${ }^{69}$ Interestingly, as will be established in Part III of this monograph, the WTO's accession process sometimes leads to a situation in which the acceding state agrees to more extensive transparency and 'rule of law' obligations. ${ }^{70}$ This finding has led some authors to conclude that the WTO may have a positive impact on the establishment of 'some democratic rights' in countries where this might - absent WTO accession - not have been the case. ${ }^{71}$ The same literature has also found that the length of GATT/WTO membership is also positively correlated with the level of political participation and the existence of due process rights in a given GATT/WTO Member. ${ }^{72}$ More recent research on the issue of whether the WTO contributes in a positive way to governance in recently acceded Members is more ambivalent. ${ }^{73}$ Although it appears that WTO accession may have some positive influence on the creation of accountable and inclusive institutions in acceded Members, quantitative analyses carried out do not provide evidence of a consistent pattern on this issue. ${ }^{74}$ It is also important to keep in mind that the WTO as an institution is focused on establishing a legal regime that is aimed at

68 See, for example, Article X:3 of the GATT 1994.

69 See, for example, Article X:1 of the GATT 1994; Article 63 of the Agreement on Trade-Related Aspects of Intellectual Property Rights, 1869 U.N.T.S. 299, entered into force 1 January 1995 (TRIPs Agreement); and Article 2(g) of the Agreement on Rules of Origin, 1868 U.N.T.S. 397, entered into force 1 January 1995 (Agreement on Rules of Origin).

70 Shaffer (2015), How The World Trade Organization Shapes Regulatory Governance, at 10.

71 Aaronson, Susan Ariel and Abouharb, M. Rodwan (2011), 'Unexpected Bedfellows: The GATT, the WTO and Some Democratic Rights', International Studies Quarterly (55) (2), pp. 379-408, at 404. See also Desta (2009), Accession for What? An Examination of Ethiopia's Decision to Join the WTO, at 361.

72 Aaronson and Abouharb (2011), Unexpected Bedfellows: The GATT, the WTO and Some Democratic Rights, at 404.

73 See, for example, Copelovitch, Mark S. and Ohls, David (2012), 'Trade, Institutions, and the Timing of GATT/WTO Accession in Post-Colonial States', Review of International Organizations (7) (1), pp. 81-107, at 104.

74 Elsig, Manfred (2013), 'The Democratizing Effects of Multilateral Organizations: A Cautionary Note on the WTO', World Trade Review (12) (3), pp. 487-507, at 504. 
facilitating the rules-based liberalization of international trade. Any positive effect that the organization has on the pursuit of other universal values such as democracy and human rights is to be welcomed, but one should remember that the main purpose of the institution was to establish a rules-based multilateral trading system. Nevertheless, accession to the WTO can contribute to economic development and the establishment of good governance in acceded Members, since the 'norms of good governance promoted by the WTO gradually filter into the polity as a whole' ${ }^{75}$

\subsubsection{Accession in Times of Regionalization and the Doha Development Round}

The negotiating arm of the WTO is often criticized for the lack of progress that has been made during the Doha Development Round, which was launched in 2001. Indeed, when put in contrast with the highly effective and successful dispute settlement mechanism, the negotiating function of the WTO may seem to be underperforming. In parallel with the slow progress of multilateral negotiations, recent decades have seen a proliferation of bi- and plurilateral liberalization initiatives, prompting some to ask the question whether the WTO 'has become passé?'76 In some instances these initiatives have led to the formation of what are termed regional trade agreements (RTAs). Nevertheless, even in times of what has been termed '(mega-)regionalisation', the WTO does not seem to have lost its appeal to states. ${ }^{77}$ Since the launch of the Doha Round in November 2001, 22 countries have acceded to the WTO. In the past four years alone, nine states have joined the organization. ${ }^{78}$ There are 19 states that have applied for WTO membership and which are currently in the accession phase. ${ }^{79}$ Consequently, it is safe to argue that the organization

75 Aaronson, Susan Ariel and Abouharb, M. Rodwan (2013), 'Does the WTO Help Member States Improve Governance', World Trade Review (13) (3), pp. 547-82, at 578 .

76 Bagwell, Kyle, Bown, Chad P. and Staiger, Robert W. (2015), Is the WTO Passé?, World Bank Policy Research Paper No. 7304, Washington, D.C.

77 Hoekman, Bernard (2014), 'Sustaining Multilateral Trade Cooperation in a Multipolar World Economy', The Review of International Organizations (9) (2), pp. 241-60, at 258.

78 Montenegro, Samoa, Russian Federation, Vanuatu, Lao PDR, Tajikistan, Yemen, Seychelles and Kazakhstan.

79 Algeria, Andorra, Azerbaijan, Bahamas, Belarus, Bhutan, Bosnia and Herzegovina, Comoros, Equatorial Guinea, Ethiopia, Iran, Iraq, Lebanese Republic, Libya, São Tomé and Principe, Serbia, Sudan, Syrian Arab Republic and Uzbekistan. 
is slowly heading in the direction of universal membership. Nevertheless, there are still 15 UN Member States and UN Observer States which are neither Members nor observer-Members to the WTO. ${ }^{80}$ The reasons behind the 'non-accession' of these states have also been researched. ${ }^{81}$ Capacity constraints, the lack of a trade-supporting domestic constituency and the lack of external pressure and/or the lack of political will have been found to explain why these countries have so far not applied for WTO membership. ${ }^{82}$ Moving forward, the pursuit of the completion of the 'shallow integration approach of traditional GATT/WTO disciplines' should be combined with new modalities aimed at tackling more novel issues in international trade. It has been argued that the WTO has not kept track with developments such as the emergence of international production networks and the associated 'supply-chain-trade'. ${ }^{83}$ The pursuit of 'critical mass agreements' or plurilateral agreements that aim to address these new realities of international commerce has been suggested as a way forward. Issues not (sufficiently) addressed by current WTO disciplines include 'tangible and intangible property rights and assurances on the free-flow of goods, services, capital, and people involved in international production networks' ${ }^{84}$ These novel developments and the future of the multilateral trading system are important. As such, they will feature in certain chapters of this monograph. Nevertheless, this contribution deals with the legal framework of the WTO as it stands. It assesses the obligations that new Members have entered into upon accession to the organization. As will be established, some of these obligations might prove to be exemplary for future disciplines that will eventually govern new generations of the multilateral trading system. However, for now, the

80 These are Eritrea, Kiribati, Marshall Islands, Federated States of Micronesia, Monaco, Nauru, North Korea, Palau, Palestine, San Marino, Somalia, South Sudan, Timor-Leste, Turkmenistan and Tuvalu.

81 Brazys, Samuel (2014), 'Outside Looking In: Non-Accession to the WTO', Cambridge Review of International Affairs (27) (4), pp. 644-65.

82 Brazys (2014), Outside Looking In: Non-Accession to the WTO, at 659.

83 Baldwin, Richard (2014), 'WTO 2.0: Governance of 21st Century Trade', The Review of International Organizations (9) (2), pp. 261-83, at 261; Hufbauer, Gary Clyde and Cimino, Cathleen (2013), 'What Future for the WTO?', The International Trade Journal (27) (5), pp. 394-410, at 407; Lamy, Pascal (2014), 'Is Trade Multilateralism Being Threatened by Regionalism?', Adelphi Series (54) (450), pp. 61-78, at 67.

84 Baldwin (2014), WTO 2.0: Governance of 21st Century Trade, at 280; MacMillan, Euan (2014), 'Explaining Rising Regionalism and Failing Multilateralism: Consensus Decision-Making and Expanding WTO Membership', International Economics and Economic Policy (11) (4), pp. 599-617. 
main focus lies on the creation of these new rules in the context of accession negotiations.

\subsection{CONCLUSION}

In this first chapter the rationale for the creation of a multilateral trading system in the aftermath of the Second World War has been explored. Initially intended to complement the Bretton Woods institutions, the ITO was in fact stillborn. The Contracting Parties to the GATT nevertheless decided to apply the tariff reduction agreement through a PPA. In the decades after the inception of the GATT, the agreement transformed into a de facto international organization with its own secretariat. Three main theories have been used to explain the creation of the GATT; however, it has been pointed out that none of these theories in and of itself fully explains the inception of the multilateral trading system. The terms-oftrade approach, the commitment theory and the foreign-policy theory should rather be seen as complementary. GATT was created as an institution with an open-door policy. Since the beginning of GATT, states and customs territories have been invited to negotiate their accession with the existing Contracting Parties. From the initial 23 Contracting Parties, GATT membership grew to 123 Contracting Parties at the end of the Uruguay Round. When the WTO was established in 1995, it had 128 Members, and over the first 20 years of its existence, this number has grown to 162. Economic considerations have been the main driver behind most accession bids. Although there has been considerable debate as to the question whether WTO membership increases trade or even welfare, the conclusion that it contributes positively to a country's economic development seems warranted. Membership of the multilateral trading system is associated with increasing levels of FDI and it is considered to contribute to good governance. Finally, it is worth recalling that the latest major update of the rules governing international trade dates back to 1995. The disciplines that govern the economic relations between countries are more than 20 years old. Multilateral negotiations towards an updated set of rules in the context of the Doha Development Round are gridlocked. Considering that the agenda for this particular round of multilateral trade negotiations was drafted in 2001, the current multilateral negotiating mandate does not seem to reflect the realities of $21 \mathrm{st}$ century 'supply-chain' trade. Numerous scholars, academics and practitioners have recognized this reality and have suggested ways of moving forward. A gradual consensus appears to be emerging that highlights the 
importance of so-called 'critical mass agreements' and plurilateral agreements. Although one can express hope that these initiatives can eventually be multilateralized in the context of the World Trade Organization, some scholars have argued that whereas the GATT/WTO multilateral trading system is based on ideas of reciprocity and the pursuit of a universal membership, according to some these concepts are fundamentally at odds with the realities of 'supply-chain' trade. As such: 'the basic deal in supply-chain cooperation is not "I'll keep my market open if you keep yours open" - as in WTO 1.0. It is "I'll offshore my factories and technologies if you assure my tangible and intangible assets are protected." 85 Some of the additional rules obligations negotiated in the context of WTO protocols of accession might prove to be initial attempts to address the realities posed by 21 st century trade. Therefore, this monograph provides an answer to the question of whether negotiations in the context of WTO accession sometimes have served as 'rule-making laboratories' in which the WTO has attempted to gradually reform some of the disciplines that currently underpin the organization.

85 Baldwin (2014), WTO 2.0: Governance of 21st Century Trade, at 280. 